\title{
Over-bureaucratisation in public procurement: purposes and results
}

JURAJ NEMEC, Prof. PhD.*

MATUS GREGA, PhD.*

MARTA ORVISKA, Prof. PhD.*

Review article**

JEL: H57

https://doi.org/10.3326/pse.44.2.5

\footnotetext{
* The authors would like to thank the two anonymous referees for helpful comments on the paper. The preparation of this paper was supported by the Slovak Grant Agency APVV, project APVV-17-0360.

${ }^{* *}$ Received: July 22, 2019

Accepted: October 19, 2019
}

Juraj NEMEC, Faculty of Economics and Administration, Lipova 507/41a, Pisarky, Brno, Czech Republic, and Matej Bel University, Faculty of Economics, Department of Finance and Accounting, Tajovskeho 10, 975 90, Banska Bystrica, Slovak Republic

e-mail: juraj.nemec@umb.sk

ORCiD: 0000-0002-5881-7422

Matus GREGA, Matej Bel University, Faculty of Economics, Department of Finance and Accounting, Tajovskeho 10, 975 90, Banska Bystrica, Slovak Republic

e-mail: matus.grega@umb.sk

ORCID: 0000-0002-8976-6867

Marta ORVISKA, Matej Bel University, Faculty of Economics, Department of Finance and Accounting, Tajovskeho 10, 975 90, Banska Bystrica, Slovak Republic

e-mail: marta.orviska@umb.sk

ORCiD: 0000-0002-8968-8483 
Abstract

Most countries spend large sums of money (10 to 15\% of their GDP) to procure goods, services and other work from private suppliers. Given this large public procurement market, it is clear that poor procurement practices might hinder sustainable development and negatively impact public finances and economic growth. This article uses data from the Czech Republic and Slovakia to show that these countries' procurement systems are over-bureaucratised, and tries to identify the causes and results of such a situation. Our findings confirm that the systems investigated are characterised by legislation that is both too detailed and frequently amended, and an administrative culture that prefers compliance to performance. With over-bureaucratisation, procurement officials opt for a Rechtsstaat administrative culture of "bureaucratic safety" that generates excessive levels of passive waste of public resources.

Keywords: public procurement, Slovakia, Czech Republic, bureaucracy

\section{INTRODUCTION}

Public procurement accounts for a very large proportion of public expenditure. Most OECD countries spend 10 to $15 \%$ of their GDP (Pavel, 2013) to procure goods, services and other work from private suppliers. Poor procurement practices might hinder sustainable development and negatively impact public finance and economic growth.

The core standard principles of public procurement are transparency, integrity, efficiency/economy, openness, fairness, competition and accountability (Pavel, 2013). The current practice stresses that organizations engaged in sustainable procurement meet their needs for goods, services, utilities and works with a view to maximizing own, but also broad social benefits, for example by taking into account environmental and social considerations. However, if too much bureaucracy is involved in public procurement, its individual and social goals are hard to achieve.

Higher transparency may, for example, in some cases lead to lower efficiency in the public procurement system, especially if it is translated into over-bureaucratisation of the procurement processes. Too much stress on process instead of results may prevent sustainable purchasing, as compliance and the lowest possible final price are the ultimate goals for purchasing entities. The above seems to afflict many developing countries, and countries with a Rechtsstaat tradition.

Our recent research mapped the core barriers limiting the efficiency of the Slovak public procurement system (Grega et al., 2019). We began with a small number of face-to-face in-depth interviews with specialist procurement advisors to contracting authorities. In the second stage, we sent questionnaires to 13,571 suppliers and to 4,300 contracting authorities. The final response rate was fully sufficient to be a representative sample. We received 211 answers from contracting authorities (4.91\% response rate) and 626 answers from suppliers (4.79\% response rate). 
Amongst other questions we asked respondents to choose up to three factors that, in their opinion, adversely affected the efficiency of public procurement. The representatives of contractors ranked excessive bureaucracy as the most important factor (143 answers); the suppliers ranked excessive bureaucracy as the second most important factor (369 answers), just three votes behind the non-ethical behaviour of public procurement officials.

The goal of this article is to use data from the Czech Republic and Slovakia to show that the situation is as complicated as the views of the Slovak procurement specialists interviewed and the respondents to our survey suggest, and to try to identify why that is, and what follows from such a situation.

The paper is based on a combination of simple quantitative and qualitative research methods. After a short literature review, the main section documents selected aspects of the over-bureaucratisation of both Czech and Slovak public procurement. This is followed by an identification of the core reasons for such over-bureaucratisation, and what consequences flow from it. A brief summary concludes.

\section{TRANSACTION COSTS IN PUBLIC PROCUREMENT}

Experts agree (e.g. Bandiera, Prat and Valletti, 2009; Pavel, 2013; Strand, Ramada and Canton, 2011) that excessive bureaucracy in public procurement increases transaction costs and may also decrease the level of competition, with negative impacts on the final outcomes from the procurement process.

Transaction costs limit the level of savings achieved by effective public procurement procedures. Table 1 indicates the differences between the estimated price and final contract price in Slovakia - we return to it in later in the text. Up to a certain level, increasing competition also positively influences the final price.

\section{TABLE 1}

The difference between estimated and contractual prices in Slovakia (\%)

\begin{tabular}{|c|c|c|c|c|c|}
\hline & 2009 & 2010 & 2011 & 2012 & 2013 \\
\hline Non-weighted difference & 7.9 & 8.8 & 11.8 & 15.0 & 11.4 \\
\hline $\begin{array}{l}\text { Weighted difference } \\
\text { (according to tender values) }\end{array}$ & -2.1 & 6.2 & 11.4 & 13.8 & 12.1 \\
\hline
\end{tabular}

Source: Compiled by the authors using data from tender.sme.sk.

The theory of transaction costs is especially associated with Coase $(1937 ; 1960)$. Later major contributions were made by, amongst others, Williamson (1985), Demsetz (1968), and Barzel (1985). Amongst Czech and Slovak authors who have written on transaction costs, Pavel $(2007 ; 2013)$ created a taxonomy of the main types of transaction costs connected with public procurement. His scheme, with some adaptations by the authors, is set out in Table 2 . 
TABle 2

Transactions costs in public procurement

\begin{tabular}{|c|c|c|c|}
\hline $\begin{array}{l}\text { Time } \\
\text { Sector }\end{array}$ & Ex-ante & On-going & Ex-post \\
\hline $\begin{array}{l}\text { Public } \\
\text { sector }\end{array}$ & $\begin{array}{l}\text { - Preparing tender } \\
\text { documentation } \\
\text { - Administering } \\
\text { tender preparation } \\
\text { fees to involved } \\
\text { external experts } \\
\text { - Legal expertise } \\
\text { costs }\end{array}$ & $\begin{array}{l}\text { - Administration } \\
\text { of running } \\
\text { tender }\end{array}$ & $\begin{array}{l}\text { - Re-start of cancelled } \\
\text { procedure } \\
\text { - Costs connected with contract } \\
\text { amendments } \\
\text { - Costs of cancellation or delay } \\
\text { - Costs connected to control/ } \\
\text { remedy procedures } \\
\text { - Legal costs }\end{array}$ \\
\hline $\begin{array}{l}\text { Private } \\
\text { sector }\end{array}$ & $\begin{array}{l}\text { - Preparing bid costs } \\
\text { to fulfil qualification } \\
\text { criteria } \\
\text { - Guarantees }\end{array}$ & $\begin{array}{l}\text { - Communication } \\
\text { with tenderer }\end{array}$ & $\begin{array}{l}\text { - Costs connected with contract } \\
\text { amendments } \\
\text { - Costs connected with delays } \\
\text { and cancellation } \\
\text { - Legal costs }\end{array}$ \\
\hline
\end{tabular}

Source: Authors, adapting Pavel (2007; 2013).

Other authors dealing with transaction costs for the Czech and Slovak Republics are Strand, Ramada and Canton (2011), Pavel (2013), Svejda (2010), and Sumpikova et al. $(2015 ; 2016)$. Svejda's estimates of transaction costs in Slovak public procurement vary between 0.25 and $5.6 \%$ of contracts' value. For the Czech Republic Pavel (2013) calculated median transactions costs per participant at $0.4 \%$ of contract value. By factoring in the probability of success in bidding, his data suggest that the winning firm's transaction costs are $4.6 \%$ of the contract's value. According to Placek, Pucek and Ochrana (2019) the core factors determining the level of transaction costs in public procurement are the quality of the legislative and regulatory framework; the type and method of procurement; the expected volume; management's experience, especially on the procurer's side; post-award behaviour and the attitudes of participants.

Excessive bureaucracy may have a negative impact on competitiveness in public procurement procedures (an issue which is in the focus of academic research about public procurement). Gupta (2002) analysed 1,937 tenders for highway construction in Florida, for 1981-1986, and found that the lowest prices could be achieved with 6 to 8 bidders. Brannman, Klein and Weiss (1987) analysed US auctions for timber and oil exploration, while Kuhlman and Johnson (1983) analysed US highway construction projects in 1975-1980. Both studies confirmed the impact of competition on the final price. Similar results were obtained by Gilley and Karels (1981); Elberfeld and Wolfstetter (1999); Szymanski (1996); and Millet et al. (2004). Pavel (2010) analysed procurement for Czech road and railway infrastructure finding that on average an extra bidder led to a price fall of $3.27 \%$. For Slovakia, Sipos and Klatik (2013) analysed all levels of procurement in 2012 with similar findings: the price decreases, at a decreasing rate, as the number of bids rises, up to a maximum of five. Similar results were confirmed by Grega and 
Nemec (2015a; 2015b), though the authors emphasise the fact that public procurement in Slovakia is the least competitive of all EU countries.

Too much bureaucracy might be one possible purpose for the limited competition in the Czech and Slovak public procurement. To participate in a public procurement procedure, potential suppliers need to cope with a lot of bureaucracy. Firms, for example, need to provide a lot of materials to confirm their compliance with the qualification requirements, generating extra costs and entry barriers, important especially for smaller firms.

\section{SELECTED EVIDENCE OF "OVER-BUREAUCRATISATION" IN SLOVAKIA}

The fact of excessive bureaucracy, and hence of excessive transaction costs in Slovak public procurement, was confirmed by Strand, Ramada and Canton (2011: 83) who estimated the administrative costs of public procurement connected with participation in above-EU threshold tenders, for 2008 (Table 3).

TABLE 3

Administrative person-day costs of EU procurement 2008 (selected countries)

\begin{tabular}{|c|c|c|c|}
\hline Country & Contractors & Country & Suppliers \\
\hline Bulgaria & 68 & Malta & 34 \\
\hline Cyprus & 44 & Slovakia & 30 \\
\hline Slovakia & 38 & Greece & 25 \\
\hline Malta & 12 & France & 10 \\
\hline Luxemburg & 11 & Finland & 10 \\
\hline
\end{tabular}

Source: Authors, adapting Strand, Ramada and Canton (2011).

During our own research in the Czech Republic (Sumpikova et al., 2016) we asked interviewed firms to estimate two things. First, the percentage of direct costs connected with the preparation of bids (including drafting a budget, a technical proposal, and bank guarantees). Second, the size of indirect transaction costs, such as legal costs in case of complaints and reviews, and fees for complaints. A summary of the responses from the statistically significant sample of building firms is provided in Tables 4 and 5.

\section{TABLE 4}

Direct costs of tender preparation by firms as percentage of estimated price

\begin{tabular}{|c|c|c|c|c|}
\hline Direct costs & Micro & Small & Medium & Large \\
\hline$>2$ & $* *$ & & & \\
\hline $3-5$ & $*$ & $* *$ & & \\
\hline $6-10$ & & $*$ & $* *$ & \\
\hline $10-15$ & & & $*$ & $* * *$ \\
\hline \multicolumn{5}{|l|}{$15-20$} \\
\hline$<20$ & & & & \\
\hline
\end{tabular}

Note: The number of * shows frequency of answers, *** means the most frequent response. Source: Nemec et al. (2016: 1753). 
TABle 5

Indirect costs of procurement by firms as percentage of estimated price

\begin{tabular}{|c|c|c|c|c|}
\hline Indirect costs & Micro & Small & Medium & Large \\
\hline$>2$ & $* * *$ & $*$ & & \\
\hline $3-5$ & & $* *$ & $*$ & \\
\hline $6-10$ & & & $* * *$ & $* *$ \\
\hline $10-15$ & & & & $*$ \\
\hline $15-20$ & & & & \\
\hline$<20$ & & & & \\
\hline
\end{tabular}

Note: The number of * shows frequency of answers, *** means the most frequent response.

Source: Nemec et al. (2016: 1753).

According to responses the core direct transaction costs are the salaries of involved employees, IT costs (especially the purchasing of necessary software), the need to purchase additional equipment (cars, copy machines, telephones), and the training of employees responsible for preparing the bid. The estimates of indirect costs are surprisingly high. The firms argued that building firms are subjects of "dirty" competition practices during tendering. Unsuccessful tenderers frequently submit complaints deliberately to slow down the tender realisation and to penalise winners. Note that winners may need to hire expensive legal services to defend their positions and their capacities reserved for this concrete bid may not be used because of tender delays. The practice may even go further - one interviewed expert in Slovakia confirmed that there are already firms that formally participate in the tender, but their aim is not to win the contract, but, when the bids have been ranked by the procurers, to contact the winner and ask for a special "fee" for agreeing not to file appeals and complaints.

Placek, Pucek and Ochrana (2019) have data showing that the probability of procurement process revisions in the Czech Republic procedures is rather high. For example, almost $1.5 \%$ of all open tenders are subject to the regulator's revision procedure. The fact that almost $20 \%$ of complaints are approved by the regulator may mean that procurers are not well qualified, but also may mean that the legislation is overcomplicated (see below).

Transaction costs also increase because of the relatively high number of cancelled tenders. In such a situation all direct and indirect costs incurred by firms are merely wasted resources. This has a really damaging impact on the procurement system (Figure 1). 
Figure 1

Number of cancelled tenders in Slovakia (in thousands)

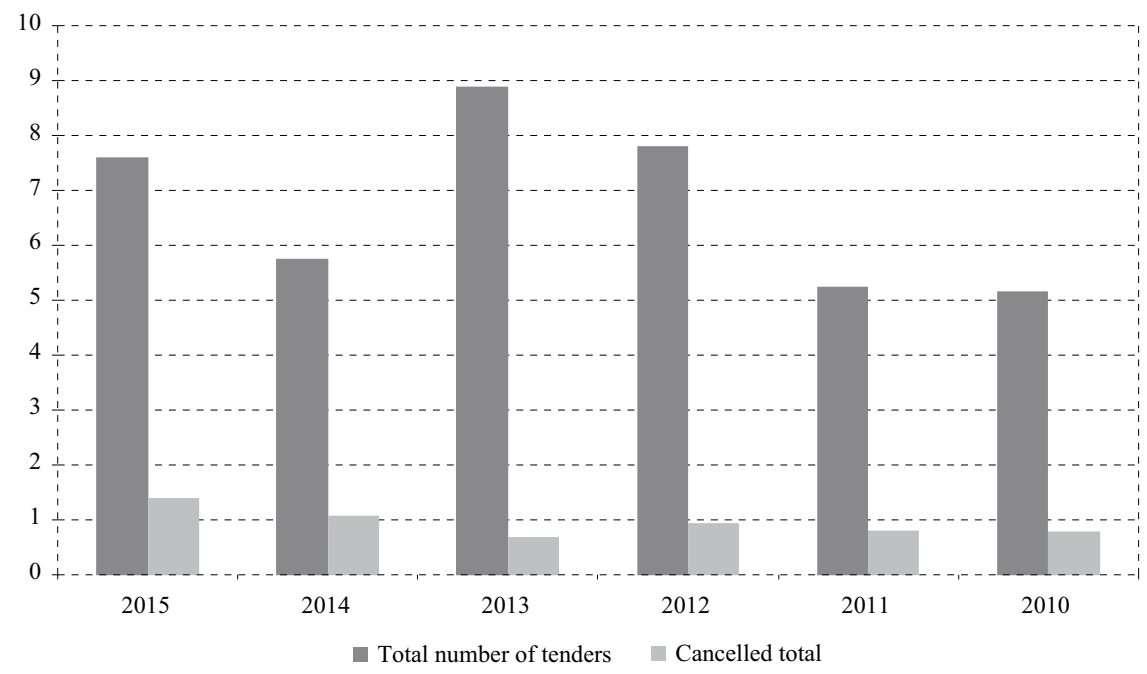

Source: Authors, data from www.uvo.gov.sk, 2016.

Over-bureaucratisation can also be documented by the legislative developments. The typical response of the Slovak and Czech governments to public procurement implementation problems, is to enshrine any changes in ever more detailed and complex legislation. We mapped two aspects - the number of changes to the Slovak public procurement law, and the number of pages of the law. This followed the methodology of Pavel (2013). Figure 2 and Table 6 show the results.

\section{Figure 2}

Legislative changes to the Slovak public procurement law

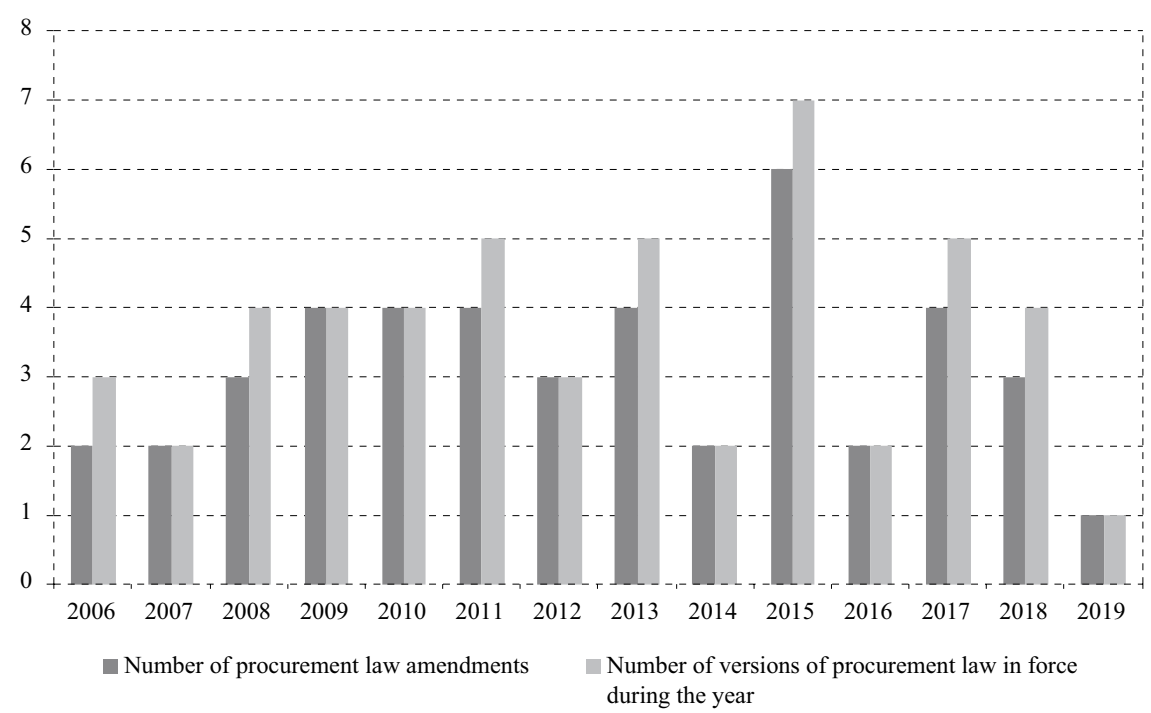

Source: Own calculations. 
Quantitative analysis of Slovakia's public procurement law

\begin{tabular}{|c|c|c|c|}
\hline \multirow{2}{*}{ Law number } & \multirow{2}{*}{ Validity date } & \multicolumn{2}{|c|}{ Normalised pages } \\
\hline & & Main text & Including annexes \\
\hline 263/1993 Coll. & $1 / 1 / 1994$ & 14 & 14 \\
\hline 263/1999 Coll. & $1 / 1 / 2000$ & 48 & 58 \\
\hline 523/2003 Coll. & $1 / 1 / 2004$ & 89 & 98 \\
\hline 25/2006 Coll. & $1 / 2 / 2006$ & 208 & 229 \\
\hline 343/2015 Coll. & $3 / 12 / 2015$ & 259 & 275 \\
\hline
\end{tabular}

Source: Own calculations (normalised page $=1800$ signs).

Frequent changes reduce the chance to deliver procurement in a legally correct way - officials may not even be able to finish re-training for a new version of the law before the next revision is passed. The enlarged law generates many concomitant regulatory and internal administrative norms. This complicates procurement execution for both suppliers and contracting authorities. Both suppliers and contractors used their options to provide verbal comments on this issue, when responding to the questionnaire. Here are two quotes to document the situation:

"The Slovak public procurement law is not for humans. It is complicated, extensive and difficult to understand. Some paragraphs lack explanations, links and implications. It requires too much in administrative actions, paperwork and time". (Contracting official)

The bureaucracy it is necessary to accept is unbelievable. I am not sure that it was proposed by a "normal human being". It must be designed by people who do not understand private business at all. (Supplier)

A comprehensive procurement bureaucracy delivers one more problematic outcome worth documenting. In a standard tender the contracting authority has the right to decide if it will select the supplier on the basis of the lowest price, i.e. the criterion of economy, or on the basis of the most economically advantageous bid, that is the efficiency criterion (the MEAT criterion). Figure 3 shows that the number of decisions based on the criterion of economy in countries like Slovakia is extremely high. This is despite the use of the criterion of economy for selecting future suppliers being a rather risky decision. 


\section{Figure 3}

The frequency of the use of the lowest price criterion to select tender winners (in \%)

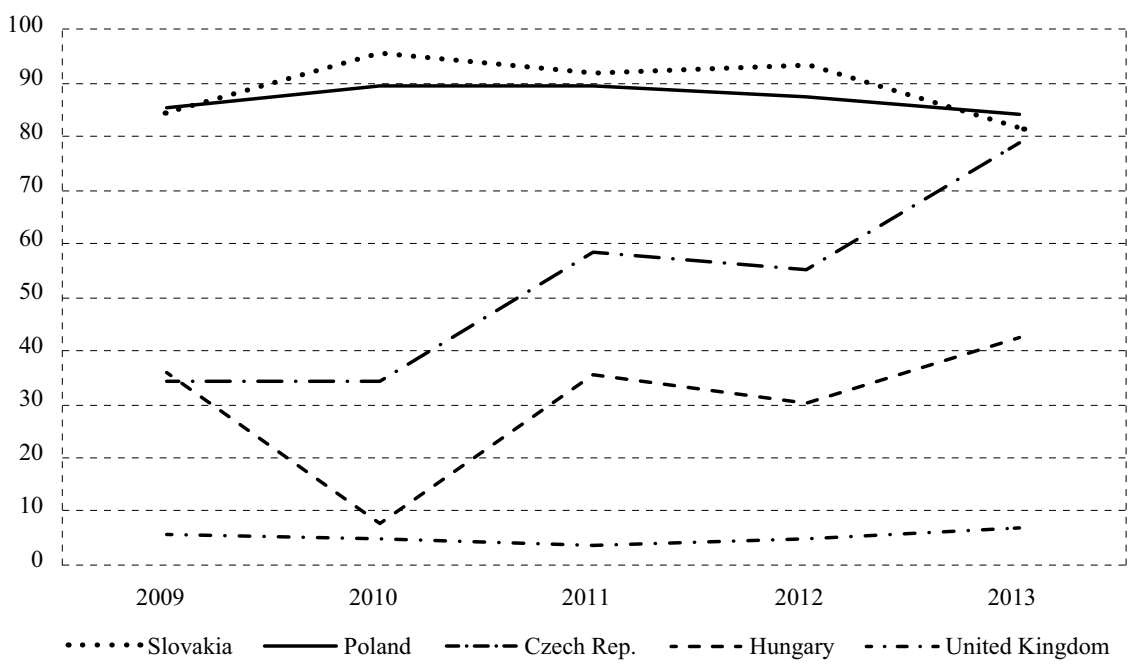

Source: Authors, based on data from Tenders Electronic Daily.

The new EU procurement directives, effective from 2014, strongly recommend not using lowest price as the selection criterion for works and services, for reasons noted above. Table 7 shows that the EU advice has largely been ignored in Slovakia.

TABLE 7

Lowest price and MEAT criteria used in Slovakia (in \%)

\begin{tabular}{|c|c|c|c|c|c|}
\hline 2018 & Lowest price & MEAT & 2019 & Lowest price & MEAT \\
\hline Works & 89 & 11 & Works & 92 & 8 \\
\hline Supplies & 93 & 7 & Supplies & 94 & 6 \\
\hline Services & 94 & 6 & Services & 94 & 6 \\
\hline
\end{tabular}

Source: Authors, data on completed tenders from Tenders Electronic Daily.

\section{CORE SOURCES OF OVER-BUREAUCRATISATION IN SLOVAK PUBLIC PROCUREMENT}

The core cause of over-bureaucratisation of public procurement, and of some other areas of public administration in Slovak and Czech Republics, is the administrative culture, which reflects wider societal and political culture and values. The European Public Administration Country Knowledge (EUPACK) summary report (Thijs, Hammerschmidt and Palaric, 2017) mapped the administrative culture in all EU countries and its connection to public administration being mostly procedural in the majority of them. According to this report, managerial public administration exists only in the Netherlands and the United Kingdom. The vast majority of new EU member states have procedural public administration systems, with the exception of Estonia, Croatia and Poland, which are characterised as mixed systems. 
A connected result is the level of regulatory density. "Red-tape" - that is a high level of regulatory density - is characteristic of all new EU members, save the Baltic States, which are assessed as having medium regulatory density. The combination of a strong procedural logic and a high regulatory density confirms the continuing high persistency of a more traditional Weberian bureaucracy in most new EU member states. This judgement has been confirmed by the Coordinating for Cohesion in the Public Sector of the Future (COCOPS) project (Hammerschmid et al., 2016).

In Slovakia, administrative tradition and culture are definitely based on the tradition of the Rechtsstaat, characterised in general by the dominant role of law and legalism in the way the government thinks and acts. Compliance is much more important than performance. If such a Rechtsstaat tradition dominates the administration of the public procurement system, which is true for the Slovak Republic, the results can be very damaging, especially because such a situation will lead to what has been called a passive waste of resources. This phenomenon has been well mapped by Bandiera, Prat and Valletti (2009) who claim that passive waste has a variety of causes, but especially important are a lack of skills and incentives to minimise costs, and an excessive regulatory burden. Their example of this burden is from the US Military, whose procurement system includes a 26-page description of chocolate cookies or brownies.

Passive waste in public procurement in Czech and Slovak conditions was first explored by Pavel (2013), and later by others, such as Sumpikova et al., (2016). The findings suggest that for example, in relation to the above described overfrequent use of the lowest price selection criterion, procurement officials are reluctant to bear the risks and extra work of using more complicated criteria. They also have only limited access to information on how to apply the MEAT criterion appropriately. The data collected by OTIDEA (Langr, 2013) throw light on the situation in the Czech Republic, where, according to the responses, $85 \%$ of procurers use lowest price as winner selection criterion, because they are afraid of complaints by bidders.

These findings not only confirm problems noted by Bandiera, Prat and Valletti (2009), but also add an additional explanation to the variety of sources of passive waste: bureaucratic safety. Public officials are not only insufficiently motivated and inadequately trained to achieve savings, but their first priority is legal safety. This requires full compliance with regulations, and is independent of the financial results of an operation. Bureaucratic safety behaviour in an already over-bureaucratised system converts the will to achieve economy or efficiency in public procurement operations into a "mission impossible".

This preference of procurement officials for safety can also help explain the results reported in Table 1 at the beginning of this text. The savings look very optimistic, but their main purpose is to over-estimate the price in the tender documentation. 
Soudek and Skuhrovec (2013) analysing electricity and gas supplies, where market price comparisons are straightforward, as both commodities are homogeneous, confirmed that the expected price in tender documentation is normally over-estimated. However, they were unsure of the extent to which the over-estimates reflect a desire to show savings in the final deal or to which they just reflect caution.

\section{CONCLUSIONS}

This article documents the phenomenon of over-bureaucratisation of the public procurement systems of the Czech Republic and Slovakia. The data collected clearly confirm that the public procurement legislation is too comprehensive and generates high transaction costs, some of which may reflect the opportunistic/ mafia type behaviour of certain tenderers.

The core finding of this paper is that in countries with Rechtsstaat-based administrative cultures, the over-bureaucratisation of public procurement, combined with limited incentives for public officials to make savings, and their preference for "bureaucratic safety", represent core barriers to achieving efficient public procurement. For most procurement officials, who focus on compliance, public procurement is simply an administrative process, and not a public financial management task. Such an environment generates excessive passive waste, whose size is as yet unknown in detail, but whose mapping may be a project for further research.

The practical question resulting from these findings is obvious: How can bureaucratic and management aspects of procurement be optimally combined, i.e. how can the level of bureaucracy in procurement be optimised? However, there is no simple answer to this question, especially for countries with administrative systems like the Czech or Slovak Republics. Long term systemic changes of the whole administrative system should be the base - the switch of focus from process to results (achieved by proper, but not too complicated procedures) is the core "medicine". Without this, although some marginal changes - like simplifying qualification procedures, formal preference to MEAT instead of price - might be possible, their impact on the system performance would be insignificant and real sustainable procurement impossible.

\section{Disclosure statement}

No potential conflict of interest was reported by the authors. 
1. Bandiera, O., Prat, A. and Valletti, T., 2009. Active and Passive Waste in Government Spending: Evidence from a Policy Experiment. The American Economic Review, 99(4), pp. 1278-1308. https://doi.org/10.1257/aer.99.4.1278

2. Barzel, Y., 1985. Transaction costs: are they just costs? Journal of Institutional and Theoretical Economics, 141(1), pp. 4-16.

3. Brannman, L., Klein, J. D. and Weiss, L. W., 1987. The Price Effects of Increased Competition in Auction Markets. The Review of Economics and Statistics, 69(1), pp. 24-32. https://doi.org/10.2307/1937897

4. Coase, R. H., 1937. The Nature of the Firm. Economica, 4(16), pp. 386-405.

5. Coase, R. H., 1960. The Problem of Social Cost. Journal of Law and Economics, 3(October), pp. 1-44.

6. Demsetz, H., 1968. The Cost of Transacting. The Quarterly Journal of Economics, 82(1), pp. 33-53.

7. Elberfeld, W. and Wolfstetter, E., 1999. A Dynamic Model of Bertrand Competition with Entry. International Journal of Industrial Organization, 17(4), pp. 513-525. https://doi.org/10.1016/s0167-7187(97)00054-4

8. Gilley, O. and Karels, V., 1981. The Competitive Effect in Bonus Bidding: New Evidence. The Bell Journal of Economics, 12(2), pp. 637-648. https:// doi.org/10.2307/3003578

9. Grega, M. [et al.], 2019. Factors Determining the Efficiency of Slovak Public Procurement. Journal of Public Administration and Policy, 12(1), pp. 43-68. https://doi.org/10.2478/nispa-2019-0002

10. Grega, M. and Nemec, J., 2015a. Factors Influencing Final Price of Public Procurement: Evidence from Slovakia. Procedia Economics and Finance, 25, pp. 543-551.

11. Grega, M. and Nemec, J., 2015b. Competitiveness in Slovak and Czech Public Procurement and its Effect on the Final Price. In V. Kajurova and J. Krajicek, eds. European Financial Systems 2015: Proceedings of the 12th International Scientific Conference. Brno: Masaryk University, pp. 143-150.

12. Gupta, S., 2002. Competition and Collusion in a Government Procurement Auction Market. Atlantic Economic Journal, 30(1), pp. 13-25. https://doi.org/ 10.1007/bf02299143

13. Hammerschmid, G. [et al.], 2016. Public Administration Reforms in Europe: The View from the Top. Cheltenham: Edward Elgar. https://oi.org/10.4337/ 9781783475407

14. Kuhlman, J. and Johnson, S., 1983. The Number of Competitors and Bid Prices. Southern Economic Journal, 50(1), pp. 213-224. https://doi.org/10.2307/ 1058052

15. Langr, T., 2013. Veřejné zakázky: ceny jsou nižší, ale ... Otidea.

16. Millet, I. [et al.], 2004. Metrics for Managing Online Procurement Auctions. Interfaces, 34(3), pp. 171-179. https://doi.org/10.1287/inte.1040.0073 
17. Nemec, J. [et al.], 2012. Transaction Costs in the Public Procurement: Selected Findings in Czech and Slovak Conditions. In P. Loster and T. Pavelka, eds. The 10th International Days of Statistics and Economics: Conference Proceedings. Praha: Melandrium, pp. 1749-1758.

18. Pavel, J., 2007. Ekonomické aspekty veřejných zakázek. Brno: Masarykova univerzita.

19. Pavel, J., 2010. Analýza vlivu míry konkurence na cenu rozsáhlých staveb v dopravní infrastruktury. Politická ekonomie, 14(3), pp. 343-356. https://doi. org/10.18267/j.polek.734

20. Pavel, J., 2013. Veřejné zákazky a efektivnost. Praha: Ekopress.

21. Placek, M., Pucek, M. and Ochrana, F., 2019. Identifying Corruption Risk: A Comparison of Bulgaria and the Czech Republic. Journal of Comparative Policy Analysis: Research and Practice, 21(4), pp. 366-384. https://doi.org/ 10.1080/13876988.2018.1472473

22. Sipos, G. and Klatik, P., 2013. Kvalita verejného obstarávania na Slovenskuv roku 2012. Bratislava: Transparency International Slovakia.

23. Soudek, J. and Skuhrovec, J., 2013. Public Procurement of Homogeneous Goods: the Czech Republic Case Study. IES Working Paper, No. 5. Prague: Charles University, pp. 1-23.

24. Strand, I., Ramada, P. and Canton, E., 2011. Public Procurement in Europe: Cost and Effectiveness. Brussels: European Commission.

25. Sumpikova, M. [et al.], 2015. Selected Factors Determining the Performance of the Czech Public Procurement System. In P. Loster and T. Pavelka, eds. The 9th International Days of Statistics and Economics: Conference Proceedings. Prague: University of Economics, pp. 1508-1517. https://doi.org/10.12955/ cbup.v3.608

26. Sumpikova, M. [et al.], 2016. Transaction Costs in the Public Procurement: Selected Findings from Czech and Slovak Conditions. In: P. Loster and T. Pavelka, eds. Proceedings from International Scientific Conference International Days of Statistics and Economics. Prague: University of Economics in Prague, pp. 1749-1758. https://doi.org/10.12955/cbup.v3.608

27. Svejda, J., 2010. Transaction Costs in Slovak Public Procurement. Prague: University of Economics.

28. Szymanski, S., 1996. The Impact of Compulsory Competitive Tendering on Refuse Collection Services. Fiscal Studies, 17(3), pp. 1-19. https://doi.org/ 10.1111/j.1475-5890.1996.tb00491.x

29. Tenders Electornic Daily. The European public procurement journal.

30. Thijs, N., Hammerschmid, G. and Palaric, E., 2017. Characteristics of EU Public Administrations: Synthesis report. Brussels: EU Commission.

31. Williamson, O., 1985. The Economic Institutions of Capitalism. New York: The Free Press. 